\title{
DESCRÉDITO DE LA VERDAD Y BANALIZACIÓN DE LA IDEOLOGÍA
}

\author{
SALVADOR GINER DE SAN JULIÁN* \\ Universidad de Barcelona
}

\author{
PALABRAS CLAVE ADICIONALES \\ Ideología, Sociología del conocimiento, Relativismo, \\ Conocimiento objetivo, Posmodernismo.
}

\author{
ADDITIONAL KEYWORDS \\ Ideology, Sociology of knowledge, Relativism, \\ Objective knowledge, Postmodernity.
}

RESUMEN. La sociología del conocimiento, y dentro de ella la de la ideología, se basan en una sólida tradición y han progresado a través del tiempo. No obstante, la expansión del relativismo en la ciencia social, por una parte, y de una simplista visión determinista, por otra, ha hecho mella en esta tradición. El presente ensayo reivindica los fueros del análisis clásico de la ideología, demuestra su valía para la sociología cognitiva (o cognoscitiva) y pone de relieve las falacias y pobreza de las posiciones llamadas posmodernas, que son las que encarnan más claramente los males que aquejan un estudio fértil y riguroso de las condiciones sociales del conocimiento objetivo.

SUMMARY. The sociology of knowledge, and within it the sociology of ideology, are grounded on a solid tradition. They have made considerable progress through time. However, the growth of a generalized relativism in social science together with that of a simplistic deterministic vision, have taken their toll of that tradition. The present essay is a plea for the virtues of the classical analysis of ideology. It shows its value for cognitive sociology today. Likewise, it unveils the fallacies and poverty of the so-called post-modern position. Criticism is concentrated on post-modernism as it embodies most clearly the weaknesses that hinder the rigorous and fruitful study of the social conditions of objective knowledge.

*El presente texto es una versión castellana, muy revisada y ampliada del capítulo "The Discredit of Truth and the Banalization of Ideology" que publique en Carlo Mongardini (comp.), Le condizioni ideologiche del nostro tempo, (Roma, Bulzoni, 1999) pp. 45-62. Agradezco a mis compañeros del Consejo de Redacción de la $R I S$ y a los evaluadores anónimos sus observaciones, que he procurado incorporar al texto.

E-mail: sginer@terra.es

Revista Internacional de Sociología (RIS)

Tercera Época, nº 31, Enero-Abril, 2002, pp. 7-34. 


\section{RIS}

Hubo un tiempo en que la ideología vino a ser una de las preocupaciones principales de la sociología. A pesar de su reciente caída en desgracia, sin embargo, el análisis de la ideología no se ha desvanecido del todo en el empeño de las ciencias sociales. Así, gran parte de la indagación sociológica - sobre todo la que se realiza en el impreciso campo de los "estudios culturales" ahora en boga - entraña no poco análisis sociológico de la ideología. En este ensayo intentaré probar que la ideología, a menudo bajo otro nombre, continúa y continuará siendo un terreno de intenso interés para la pesquisa, la crítica y la especulación sociológicas. Espero demostrar que la posibilidad de que los procesos ideológicos dejen de constituir una preocupación sociológica fundamental es, a no dudarlo, muy remota.

Pretender que la tradición intelectual que se halla tras el estudio de la ideología no ha sufrido cierto declive en tiempos recientes sería insostenible. También ha sufrido reveses. Si comparamos lo que hoy se hace en este tefreno con lo que se solía en el pasado, habrá que constatar que hay una pérdida sustancial de interés en el estudio de la ideología, sobre todo según los cánones establecidos por la tradición de la ciencia social. Sus tareas se llevan a cabo ahora bajo un nuevo vocabulario y desde perspectivas metodológicas asaz distintas de las que prevalecían no ha mucho tiempo. La ciencia cognitiva, por un lado, $\mathrm{y}$, desde un ángulo muy distinto, incompatible con ella, el relativismo moral y cognoscitivo de los últimos decenios, por otro, han socavado los postulados tradicionales mediante los cuales se cultivaba el estudio de la ideología. A través de él se realizaba la ardua búsqueda de conocimiento objetivo. Porque el ímpetu esencial para el desvelamiento de la ideología no era otro que el de la búsqueda de la verdad.

\section{EL ANÁLISIS SOCIOLÓGICO DE LA IDEOLOGÍA}

Hay aún quienes continúan cultivando un campo —el estudio y crítica de la ideología - que había llegado a convertirse en uno de los temas nucleares de la sociología, y en especial de la del conocimiento. Se trataba originalmente de una empresa que no significaba necesariamente la subyugación a los métodos y criterios de una escuela única o perspectiva cerrada. Así, hasta en el momento culminante del influjo y popularidad del marxismo, con su señera aportación a la crítica de la ideología, ésta no tenía por qué estudiarse solamente según sus criterios. Cierto es que, a partir de 1927, merced a la aparición de la obra, hasta entonces inédita, de Marx, La ideología alemana, $\mathrm{y}$, más tarde, gracias a la difusión de la noción siempre interesante de "hegemonía", forjada por Grasmci, se fue fraguando toda una corriente de reflexión y esfuerzo teóricos dedicada a la ideología dentro del campo marxista, a la sazón tan floreciente. No obstante, las aportaciones de los 
autores extraños al marxismo no fueron menores durante esa misma época. Nada menos que el teórico clásico más descollante en el estudio de la ideología, Karl Mannheim, aunque "marxistizante" en alguna faceta de su obra, no era precisamente marxista.

El hecho bruto es que desde sus inicios la teoría y el estudio de la ideología no se dejaron circunscribir a un solo enfoque. A lo sumo podría aducirse que quienes en su día apoyaron lo que ellos mismos llamaron sociología crítica (o radical o sencillamente, de izquierdas, por usar expresiones que siempre han dejado mucho que desear, pero que son elocuentes de su propia posición ideológica) solían inclinarse más que sus rivales conservadores hacia el estudio de la ideología. Pero eso fue todo. Entrambos, radicales y conservadores (si aceptamos para entendernos estos apelativos tan espinosos en el ejercicio de la sociología) se interesaron seriamente por el estudio de la ideología, por el de las condiciones sociales de la verdad y por la relación entre ésta y sus adulteraciones y tergiversaciones.

Se entiende que la ideología ocupara un lugar menor en los enfoques funcionalistas y estructuralistas en los días triunfales de estas escuelas, los decenios de 1950 y 1960. Mas la noción, nunca monopolizada por los marxistas, se usaba por parte de sociólogos de toda suerte, incluso por parte de varios de los que trabajaban dentro de la tradición fenomenológica. Las diferencias de énfasis vinieron a ser lo más importante. Para algunos de ellos, la emancipación intelectual (o sea, sacudirse de encima toda ideología) era la tarea más importante a que pudiera entregarse un sociólogo. Nuestro oficio consistía, según estos autores, en desvelar, desenmascarar y poner en evidencia las fuerzas del mal, escudadas tras sus ladinas ideologías. (Las afinidades de tal tarea con la revelación de los autoengaños y la mala fe anímicos a la que mientras tanto invitaban los psicoanalistas o los filósofos de existencialista inclinación a sus respectivos públicos, eran evidentes, al margen de que los respectivos feligreses de estas escuelas a veces anduvieran a la greña entre sí). Para otros, la ideología era un elemento inevitable en toda vida social: lo único que cabía esperar era, en algunos casos, un amortiguamento de las distorsiones ideológicas de la verdad. Pero todos reconocían que la ideología era una característica identificable de la cultura humana, un elemento fundamental de toda civilización. A lo sumo, algunos pensadores asumían que podría amanecer, en el porvernir, una civilización libre de servidumbres ideológicas.

Para quienes concebían la cultura "verticalmente" —como una estructura de dominio - la ideología constituía un fenómeno en el que se plasmaba la clase, el poder y el privilegio, y por lo tanto era su columna vertebral. Cultura e ideología se hallaban inextricablemente enlazadas. La cultura "burguesa" o "capitalista" se definía en términos de dominación y supeditación. En cambio, para aquéllos que la entendían de modo más "horizontal" - como universo compartido de valores y concepciones que unía a la gente en comunidades de identificación 
RIS

REVISTA INTERNACIONAL DE SOCIOLOCÍA

№ 31, Enero-Abril, 2002

SALVADOR GINER DE SAN JULLÁN

y sentimiento-, la ideología se percibía como algo más difuso, con menor peso en su función de estructurar jerárquicamente nuestras relaciones sociales. Mas nadie - ni los verticalistas, a menudo marxistas, ni los horizontalistas, con frecuencia funcionalistas- negaba su existencia.

El amplio reconocimiento del gran alcance de la ideología inspiró aportaciones notables. Algunas de ellas se realizaron dentro y fuera de la tradición marxista en los largos decenios durante los cuales se pensó que la ideología era componente crucial de cualquier cultura, así como elemento esencial de la producción social del conocimiento y la creencia (Gurvitch, 1966). Hasta los investigadores más positivistas de aquel período coadyuvaron al progreso en este campo mediante su insistencia en el análisis de contenido ${ }^{1}$ y en el estudio del lenguaje, imaginación y metáforas empleadas en las manifestaciones ideológicas, propagandísticas, estratégicas, gremiales y demás.

Nadie osó sugerir que la ideología o sus equivalentes no eran fenómenos sociales clave necesitados de estudio imparcial y sosegado. La ideología debía someterse a examen como debían desvelarse los intereses, intenciones y ocultaciones de sus beneficiarios, así como las desventajas, daños y sufrimientos de sus pasivos receptores o crédulos seguidores. Era ésta una faena esencial si queríamos de veras mostrar y entender la estructura y dinámica de cualquier sociedad y su cultura, así como las estrategias y fines (a menudo escondidos) de las gentes que las defendían. Los sociólogos de las más diversas escuelas sostenían que la comprensión del mundo social no podía completarse sin excavar los fundamentos de las afirmaciones, justificaciones y explicaciones percibidas o presentadas como verdaderas, así como desentrañar los mitos, metáforas e imágenes en que éstas se encarnaban. La "desmitificación" y el "desvelamiento" eran tareas supremas (prácticamente, imperativos morales de la ciencia social.) Fue así como la sociología misma vino a ser definida por algunos autores, no necesariamente radicales, como disciplina esencialmente desmitificadora.

Para los menos utópicos del gremio, desmitificar y desvelar entrañaba un coste, que la herencia de Simmel y Weber había señalado con el consabido acierto, a saber: el desencanto del mundo. A este convencimiento no escapaban ni quienes preconizaban la necesidad de respetar "la sabiduría práctica de la gente" a través de la cual los seres humanos desarrollamos nuestras destrezas para la interacción, nuestros rituales y liturgias cotidianos. Quienes así pensaban, sobre todo los llamados etnometodólogos, que surgieron como escuela distinta e

\footnotetext{
${ }^{1}$ La permanencia de este enfoque a principos del siglo XXI a través del análisis del discurso -planteado en 1966 por Émile Benveniste - no debe ocultarse a nadie, por mucho que la literatura y trabajos que se realizan bajo el nuevo enfoque ignoren a menudo sus raíces en el tradicional análisis de contenido y su parentesco con él.
} 
identificable a partir de los últimos años 60 , acusaron a sus colegas sociológicos de "legislar" demasiado acerca de las creencias e interpretaciones de la gente. Pensaban que ésta sabía más acerca de la sociedad de lo que la propia sociología "normal" (convencional o predominante) asumía. No obstante, con su característico estilo etnometodológico, afirmaban que su tarea era de descubrimiento (una vez más, de desvelamiento), compartiendo así el esfuerzo de toda ciencia social por conocer con alguna certidumbre. Los etnometodólogos de ayer (como sus herederos más o menos reciclados de hoy) nunca negaron, pues, la ideología. Solamente se acercaron a ella desde otro flanco. En los términos propios de la sociología del conocimiento y de su rama más tradicional, la del estudio de la ideología, sus discrepancias eran menos profundas de lo que parecían en el fragor de las ruidosas, aunque incruentas, batallas de los años 60 y 70 del siglo recién pasado. La etnometodología fue siempre pugnaz y sus cultivadores se presentaban casi siempre como radicales y esencialmente diferentes, aunque no lograran convencer de ello a quienes no eran sus secuaces.

El paso del tiempo ha mostrado dos cosas. La primera es que la presencia de la escuela etnometodológica fue cuasi episódica, aunque significativa, y a juicio de muchos que jamás se sintieron seducidos por ella, beneficiosa para el progreso de la ciencia social. (Fenomenólogos y etnometodólogos ayudaron a desbrozar el campo, por lo menos). La segunda es que no logró hacer auténtica mella sobre las nociones básicas de la sociología acerca de la naturaleza de la ideología y de la práctica ideológica, ni tampoco en su búsqueda de conocimiento objetivo y veraz.

El caso es que la ideología se había ya consolidado como uno de los temas nucleares de indagación para la ciencia social. Y ello hasta tal punto que los ataques que se montaron contra algunas de sus manifestaciones tan sólo reforzaron la importancia que se le atribuía. Poseemos ya suficiente perspectiva para saber que El fin de la ideología de Daniel Bell, en 1960, tan sólo anunciaba la muerte de cierta suerte de ideología política, no de la ideología en sí. Nunca pretendió Bell que las tendencias ideológicas, las distorsiones interesadas, la fragua de los mitos y la manipulación del conocimiento, iban a agotarse. Su libro llevaba el elocuente subtítulo Sobre el agotamiento de las ideas políticas en los años cincuenta y era inequívoco. (Cabe preguntarse si quienes no leyeron el libro, pero arremetieron contra Bell, hoy justamente olvidados, leyeron por lo menos el subtítulo.) Lo mismo puede decirse de las aportaciones prácticamente simultáneas sobre lo mismo de Raymond Aron, Seymour Martin Lipset y Edward Shils, así como las de su contrincante C.W. Mills, a cual más perspicaz. Ninguno pretendía otra cosa, como Bell mismo recordaría más tarde, que afirmar que, en los años cincuenta del siglo XX, "las antiguas ideas políticas del movimiento radical se habían agotado" y que ya "no tenían la capacidad de lograr la obediencia 
RIS

REVISTA INTERNACIONAL DE SOCIOLOGIA

№ 31, Enero-Abril, 2002

o la pasión de la intelligentsia"2. Certificar el ocaso de ciertas ideologías no significa anunciar el fallecimiento de la ideología.

Carece de sentido revisitar aquí el notorio debate sobre el fin de la ideología desencadenado por las afirmaciones de Aron, Bell, Shils y otros. Es un episodio muy bien conocido en nuestra historia intelectual reciente que, sin embargo, tal vez merezca ser reconsiderado con serenidad algún día. Lo único que es menester traer a colación aquí es que si la ideología, como campo de indagación, parece haber perdido hoy parte del atractivo que tuviera en otros momentos, ello no se debe a las consideraciones y críticas lanzadas por aquellos observadores contra la cerrazón ideológica, el dogma político y la esclavitud mental de quienes pusieron su inteligencia y albedrío al servicio de dudosos poderes mundanos y en nombre de un peregrino "compromiso" del intelectual. (¿Compromiso con quién, con un abstracto proletariado? ¿Con su vanguardia monopolizada por un partido único y dictatorial? ¿Con las férreas leyes de la historia, por todos desconocidas?) Si sus críticas no se hubieran extendido también al propio capitalismo (véase Las contradicciones culturales del capitalismo, de Daniel Bell, o cualquier estudio de C.W. Mills) habría razón para sospechar de ellos mismos como ideólogos capaces sólo de practicar la crítica de una sola ideología, la única que no les plugo. Pero no fue así. Lo significativo es que, pasara lo que pasara en aquellos tiempos crispados - la llamada Guerra Fría perdonó a muy pocos-, la ideología en sí, tanto en general como en sus manifestaciones específicas, continuó atrayendo la atención merecida. Fue así como, en la sociología del conocimiento, la noción y la teoría de la ideología nunca cayeron en lo banal ni en lo caprichoso entre sus estudiosos serios de la época. Sus raíces se hundían en una de las tradiciones epistemológicas más señaladas de Occidente.

En efecto, los fundamentos remotos de esa teoría habían sido elaborados poco a poco, extendiéndose desde el platónico mito de Er hasta la doctrina de los ídolos de Bacon. Los protosociólogos de la Ilustración buscaron en esta última la idea de que los dioses e ídolos que adoramos no son sólo los prescritos por nuestra fe religiosa y los mitos recibidos, sino también los forjados por el teatro o comedia de nuestras vidas, o por el mercado y la plaza pública, junto los engendrados intencionalmente por el poder y la política. Los hombres, pensaban, no sólo creían con frecuencia en cosas que eran manifiestamente falsas, sino que porfiaban entre sí por inducir a otros a que creyeran en aquello que podía convenirles o favorecerles a ellos mismos, sin el menor respeto por la verdad. Los hombres se inclinaban así a la producción de idola, mentiras sociales,

${ }^{2}$ Bell (1976: 5-6). Para una manifestación temprana de la llamada "tesis del fin de las ideologías", ver Aron (1955). 
fantasías políticas y explicaciones sin fundamento, con tal de forzar o seducir a los demás a creer en ellas, si les eran ventajosas. Para descubrir una realidad más profunda era menester penetrar el denso velo de embustes, supercherías y mitos urdidos por la humanidad ya con alevosía, ya con inocente buena fe. Todo ello estaría o no vinculado a estructuras sociales y culturas determinadas, pero venía también uncido a nuestra condición como seres forjadores de dioses a los que adorar o temer, a los que aplacar u obedecer (Moscovici, 1988).

Andando el tiempo, el gran movimiento ilustrado contra la superstición, las falsas creencias y los mitos supuestamente infundados estaba destinado a ser visto con condescendencia precisamente por quienes heredaron algunos de sus efectos beneficiosos. Así, los etnólogos e historiadores de la época romántica pensaron que el racionalismo había ido demasiado lejos: relatos fantásticos, religiones y mitos escondían en realidad verdades profundas. Los savants dieciochescos habían sido arrogantes e ingenuos al descalificar las creencias populares. Esta comprensible reacción (no del todo justa, ciertamente, con los pobres savants) constituyó un paso adelante para el desarrollo de una epistemología de las creencias, absolutamente necesario para la fundamentación ulterior de una teoría rigurosa de la ideología. Cuando llegó el momento, tal teoría se constituyó como parte esencial de la epistemología en general, y no sólo de la ciencia social. No fue casual que la sociología del conocimiento impulsada por Mannheim fuera precedida por la del saber o Wissensoziologie propuesta por Max Scheler, ni tampoco que, mucho antes, Marx hubiera intentado vincular las nociones abstractas de razón y racionalidad hegelianas a su anclaje real, económico, político y administrativo. Para todos estos autores, de tan distinta y hasta opuesta inclinación, captar las "condiciones sociales de existencia" del conocimiento humano no amenazaba la presencia última de la verdad. Descubrir una ideología significaba sólo identificar un escollo más a sortear en nuestra ardua e inacabable senda hacia ella. Tal identificación constituía un triunfo, y no minúsculo. Sabíamos a qué atenernos en nuestra faena: teníamos que habérnoslas primero con el cedazo de la sociedad para acceder racional y científicamente a mayores certidumbres, después.

El descubrimiento de la ideología, pues, no relativizó la verdad. Para empezar, las condiciones del conocimiento no se consideraban como todo lo que había que saber respecto a él. De hecho, la aportación que la sociología de la ideología realizó a la epistemología moderna consistió en hacerla consciente de que el análisis sociológico de las ideas y las creencias suele ser, necesariamente, un paso preliminar en nuestra empresa de intentar alcanzar la verdad de las cosas. El único relativismo propio de esta posición es un "relativismo metodológico". Se reconocían sesgo o biés y distorsión (¿qué palabras hay que sean más sociológicas que éstas?) en las percepciones, concepciones e interpretación del mundo de las gentes. Se asumía así un perspectivismo moderado por la noción de conocimiento objetivo, no un perspectivismo radical que degradaba la certidumbre a mera opinión. 
RIS

REVISTA INTERNACIONAL DE SOCIOLOGI

№ 31, Enero-Abril, 2002

SALVADOR GINER DE SAN JULIÁN

Merced a la entonces nueva sociología del conocimiento se hizo imperativo describir con precisión la situación social y las creencias con el fin de abrir la senda hacia un universo de nociones, proposiciones y asertos, tan libre de tergiversaciones como fuera humanamente posible. La acusación de que el estudio tradicional de la ideología es totalmente relativista carece, pues, de fundamento. Tal estudio estaba tan consciente del peso de la ideología como del hecho de que la pesquisa de la verdad no es tarea vana. La verdad, claro está, era difícilmente alcanzable. O era inalcanzable. Pero la había. Como había falsedad. Para acercarse a la primera, había que identificar y demoler la última.

\section{LA CRÍTICA IDEOLÓGICA DE LA SOCIOLOGÍA}

Los sociólogos no salvan su propia disciplina de las atenciones más delicadas. (En efecto, abierta o tácitamente, la "sociología de la sociología" es una de sus ocupaciones más características. En ello contrastan con sus colegas de otras disiciplinas afines, menos intensamente introspectivos respecto a su propia faena). Andando el tiempo, y a medida que fue desarrollándose el estudio sociológico de la ideología (y del conocimiento), creció también de modo irresistible la tentación de someter a la sociología al mismo análisis sociológico al que ya se habían sometido programas políticos, campañas de prensa, políticas científicas, doctrinas filosóficas y expresiones literarias o artísticas. De tal modo, el escrutinio del biés ideológico alcanzó a la misma sociología. Fue un paso legítimo y enteramente lógico.

Si contemplamos la abundante literatura producida en los decenios de 1960 y 1970 bajo la etiqueta de "sociología crítica", debe concluirse que el ejercicio fue, en su conjunto, saludable ${ }^{3}$. Un parecido escrutinio se extendió pronto a otras disciplinas. Surgió así una "economía crítica". (Ésta nunca logró ocupar el centro de la disciplina, empero, arrinconada pronto por el auge del monetarismo, del neoliberalismo y las pretensiones de cientificidad de la econometría). Por su parte, la "antropología crítica" consiguió provocar más de un revuelo en los medios etnológicos, con su celo autocrítico y su ligamen con la nueva inclinación de atacar las ciencias sociales por su presunto eurocentrismo y sus también presuntas connivencias ideológicas con el imperialismo occidental. En todo caso, la acusación de eurocentrismo no quedó confinada a la antropología, puesto que

\footnotetext{
${ }^{3}$ Es imposible presentar aquí una lista completa de las publicaciones sociológicas dedicadas a "denunciar" o "desenmascarar" ( $\mathrm{sic}$ ) los intereses ocultos de la sociología o sus cultivadores y sus distorsiones ideológicas. No obstante, puede verse F. Ferrarotti (1972), S. Giner (1994), A. Gouldner (1970) y C.W. Mills (1959).
} 
una parte sustancial de la llamada sociología crítica también vino a castigarla - a autoflagelarse - acusándola de reflejar una versión occidental de la verdad (McLennan, 2000, y Sebreli, 1992). Si bien conviene aceptar lo que de autocrítica genuina y razonable hubo en esta corriente, es de lamentar que sus representantes ignoraran sistemáticamente el logro muy considerable de los pensadores sociales occidentales. A pesar de todas sus limitaciones, desde Vitoria, Las Casas y Montaigne hasta Spencer y Durkheim (pasando por Las cartas persas de Montesquieu y Las cartas marruecas de Cadalso), el empeño por vernos a nosotros mismos desde fuera, por así decirlo, por llamar la atención ante el hecho de que los occidentales no estamos en posesión de la verdad, ha sido consustancial a nuestra propia tradición. Tal vez haya sido eurocentrista, aunque no tanto como la China ha sido "sinocentrista", ni otras civilizaciones que se han lucido en su empeño por tomarse a sí mismas como vara de medir el mundo. No obstante, la nuestra ha sido prácticamente la única que ha hecho un inmenso esfuerzo por contemplarse, con la debida ironía y distancia, como ajena a sí misma. ¿O es que Montesquieu es un episodio marginal de la historia cultural occidental?

El origen de la corriente crítica de la sociología contra la penetración de la ideología en su propio seno se halla en la obra de C.W. Mills La imaginación sociológica, de 1959, aunque precedida por el absurdamente olvidado Modas y flaquezas de la moderna sociología y ciencias afines de Pitirim Sorokin. Su estilo vigoroso, radical, libertario y con frecuencia cuasi periodístico, inspiró el tenor para el ataque antisociológico que perpetraron no pocos sociólogos (Mills, 1959, y Sorokin, 1956). Sus objeciones iban, en primer lugar, contra la (poco latente) posición conservadora del principal teórico de su tiempo, Talcott Parsons, pero extendían su manto bastante más allá. Dada su popularidad -reforzada por una cierta marginación institucional, que recordaría a la sufrida en su tiempo por Simmel si las razones de la una no fueran tan distintas de las de la otra-Mills preparó como nadie el terreno para lo que se avecinaba. También lo hizo Alvin Gouldner un tiempo después, cuando amplió sus críticas a doctrinas muy amplias (aunque empezando también por habérselas con Parsons), como la ideología utilitarista predominante en el Occidente del liberalismo capitalista, una corriente que, según él, había tergiversado por completo la sociología occidental, cuya inminente crisis final anunció con talante profético. (Su prematura muerte, en Madrid, no le permitiría comprobar que la crisis por él anunciada iría tardando tanto en llegar como Godot al escenario). Ni Mills ni Gouldner eran amigos de las concepciones criptostalinistas de una parte yerma y menor de la sociología, y menos aún de las que conducirían poco tiempo después al callejón sin salida del althusserismo. Sin embargo, ambos vislumbraron en el marxismo occidental virtudes de las que la sociología del momento (entiéndase la parsoniana y otras variedades del funcionalismo) carecía. Mills, Gouldner y Birnbaum, entre otros, se sintieron inspirados por un espíritu de cruzada contra 
el sesgo ideológico conservador presente en la sociología de algunas notorias escuelas. Con ello contribuyeron a que el análisis de la ideología incluyera también el de la propia sociología. Como debe ser. Hacer explícita la relación entre teoría y política, en cualquiera que sea la disciplina, es parte de nuestra empresa. Si los sociólogos exploran los ligámenes de los proyectos de investigación que se llevan a cabo en energía nuclear o bioquímica con las políticas de defensa o agresión de cada país, tampoco hay razón alguna para que libren de su escrutinio los lazos que hay entre los enfoques sociológicos, económicos o de otra índole científicosocial en el mundo académico, con las orientaciones de los gobiernos que controlan la política educativa o las grandes fundaciones que financian y privilegian ciertos enfoques en lugar de otros.

Nuestra deuda con esta generación de sociólogos desveladores de ideologías e intereses implícitos no acaba aquí, si bien es cierto que la introspección que nos caracteriza como gremio no la inventaron ellos. En todo caso, sus inmisericordes críticas contra ciertos aspectos complacientes de la doctrina funcionalista y estructuralista y contra los abusos del positivismo, fueron muy a menudo certeros, amén de que sus intenciones fueran loables ${ }^{4}$.

Ello no impidió que algunos de los seguidores de estos briosos críticos de su propia disciplina cayeran presa en un gauchismo sociológico que se confundía ocasionalmente en el periodismo agitado. Se extendió así como actividad principal de ciertos sociólogos la manía de desenmascarar, acusar y denunciar en detrimento de la crítica rigurosa, sensata y parsimoniosa de la ideología (dentro y fuera de la sociología), que es la que debe cultivarse dentro de la disciplina. Los sociólogos, claro está, no deben callar si algunos colegas caen en el colaboracionismo con regímenes políticos abyectos (Giner, 1965) o cuando olvidan su tarea normal de realizar una crítica secular del mundo según criterios cívicos elementales. Empero, tampoco deben permitir (por respeto a su propia discipina) que la necesaria vigilancia ideológica engulla toda su actividad. Descalificar la obra ajena, por lo ideológicamente sesgada, sin mayor abundamiento, ni una evaluación aunque sea mínima de la posición propia, no exonera de ejercer las otras tareas que acarrea el oficio de sociólogo.

La inclinación hacia el desvelamiento de distorsiones ideológicas en la ciencia social llegó a ser tan intensa que el adjetivo de "crítico", y sobre todo la noción legitimadora de "crítica", pronto adornó los títulos de ensayos, escritos y tratados producidos por no pocos científicos sociales "convencionales". (El adjetivo cristalizó en un principio con la Escuela de Francfort, con su pretenciosa noción de Teoría Crítica, que se atribuyó a sí misma para darse un nombre

\footnotetext{
${ }^{4}$ La lista de publicaciones dentro del movimiento de la llamada sociología crítica es tan larga, que me limito a referirme a N. Birnbaum (1971) y J.D. Colfax y J.L. Roach (1971).
} 
impecable, y negárselo implícitamente a los demás, por vía de logotipo). Si la sociología es crítica, además de autocrítica, ambas cosas por definición, salvo en sus productos más banales y rutinarios (gran parte de la sociología producida por consultorías y muchos sondeos de opinión caen en esta categoría), uno se pregunta si para tal viaje (no siempre a lugar conocido) hacían falta tales y tan huecas alforjas. Como en cualquier otra disciplina, surgen en ella trabajos tediosos, repetitivos y triviales, en los que ni por asomo se vislumbra una hipótesis medianamente interesante o en los que brilla por su ausencia toda reflexión crítica que pueda enojar al cliente. Por otra parte, las especulaciones, teorías y estudios ideológicamente manchados son tan frecuentes en sociología como en ciencia política, economía, historiografía y antropología.

Nadie afirma, ni mucho menos el autor de estos renglones, que no debamos enmendar cualquier fallo ideológico que a nuestra disciplina afecte. Pero hay que preguntarse qué desazón y angustia se apoderó de tantos sociólogos durante casi dos decenios como para sentirse, muchos de ellos, posesos por una avidez de crítica a su propia tarea rayana en la autoflagelación. En algunos casos, esa avidez fue superior a su afán por fortalecer la disciplina con los frutos de sus indagaciones sociológicas empíricas. No fue ése el caso de quienes iniciaron la autocrítica sociológica. Así, la autoridad intelectual de Mills y de Gouldner proviene de habérselas habido también con "la realidad". En efecto, nadie puede ignorar estudios, hoy clásicos, como La élite del poder o La huelga salvaje. Son investigaciones realizadas con el mismo entusiasmo que dedicaron a la crítica ideológica de la sociología que era, a la sazón, hegemónica en su país.

Una faceta poco feliz de aquella desdichada situación fue la abundante literatura de la época dedicada a diagnosticar la inminente "crisis de la sociología". Como acabo de indicar al referirme a la incumplida profecía de Gouldner, la crisis no ha tenido lugar. Tenemos nuestros duelos y quebrantos, cómo no, unos endémicos, otros circunstanciales. Nos parasitan otras disciplinas, tal vez azuzadas por lo mucho que parasitamos nosotros a las demás. Caen en desgracia, a veces, nuestros desvelos en los ministerios de enseñanza pública que nos han de asignar un lugar en el sol de la Academia. Las empresas nos usan en lo más trivial e ignoran en lo más sustancial. Los políticos y los responsables de la economía no siempre tienen en cuenta los avisos que les damos sobre la evolución del mercado de trabajo, las migraciones, la delincuencia, el prejuicio racista, las consecuencias de esta o aquella política educativa, y así sucesivamente. Pero esto es harina de otro (y muy relleno) costal. No entraña la supuesta "crisis" de la disciplina, sino su endémica condición incómoda en el mundo. Quien no la acepte debería dedicarse a otros menesteres.

Por lo que atañe de veras a lo que relato, recordemos que la moda de las jeremíadas sobre la inminente crisis de la sociología fue breve. Podría haber durado más de lo que duró, si no hubiera sido por un acontecimiento exterior a la disciplina, que forzó a los sociólogos, incluso a los que habían 
RIS

REVISTA INTERNACIONAL DE SOCIOLOGIA

№ 31, Enero-Abril, 2002

SALVADOR GINER DE SAN JULUÁN

proclamado las presuntas miserias ideológicas de su propio oficio, a cerrar filas en su entorno.

Así, durante los últimos años 70 y a lo largo de los 80 del siglo $\mathrm{XX}$ algunos políticos y hasta gobiernos neoliberales en el Reino Unido y los Estados Unidos se tornaron claramente hostiles a la disciplina. La consideraban instigadora de radicalismo de izquierdas, y en algún caso como de inspiración marxista. Los sociólogos que hasta ese momento se habían dedicado alegremente a socavar su propia disciplina a causa de su presunto conservadurismo y colaboracionismo con las potencias siniestras del capitalismo, el imperialismo y demás fuerzas del mal, la veían ahora acusada de peligroso radicalismo por parte de los políticos conservadores y sus ideólogos, a menudo desde los medios de comunicación. Alguaciles alguacilados. Habrá que pensar que los más apocalípticos de los sociólogos críticos de aquellos tiempos, cuyos nombres omitiré piadosamente, algunos de los cuales prosperan hoy en la industria retórica de la antimundialización, tienen una parte de responsabilidad en la recesión académica de la sociología acaecida en varios países en los que la disciplina había alcanzado gran calidad. De ella nos estamos aún recuperando, que no de una crisis inexistente.

Aunque pueda parecer sorprendente, los sociólogos se dieron cuenta, aunque con lentitud, de que hay una distinción crucial entre, por un lado, el debate y las pugnas entre diversas escuelas y por otro una puesta en tela de juicio general e indiscriminada de la propia disciplina. Por fortuna hay por fin señales de que es posible realizar esfuerzos que nos conduzcan a una mayor integración teórica entre escuelas muy distintas y hasta antagónicas entre $\operatorname{si}^{5} \sin$ que se evoquen los fantasmas que ayer pusieron en peligro el arte que cultivamos, asaltado por nosotros mismos, o al menos por un caballo de Troya repleto de sociólogos. Esperemos, sin embargo, que el nuevo estado de ánimo no anuncie otro período de autocomplacencia. La sociología debe continuar siendo autocrítica, pero por otros medios, distintos de los de sus fracasados debeladores surgidos de la propia profesión.

Aprendamos del episodio de la "crítica ideológica de la sociología". La extensión del análisis de la ideología a las ciencias sociales y a la sociología misma (que es la que normalmente la realiza) es un ejercicio enteramente legítimo y, además, saludable. Cuando se lleva a cabo con el debido rigor constituye una aportación interesante a nuestro esfuerzo por desbrozar lo falso

\footnotetext{
${ }^{5}$ N. Mouzelis (1995) es un ejemplo de tal esfuerzo integrativo. Su libro lleva el elocuente título y subtitulo de Sociological Theory, What went Wrong? Diagnosis and Remedies. Estudios como ése anunciaron el nuevo tenor, ya más sereno, que se ha instaurado en la indagación sociológica.
} 
de lo posiblemente cierto. El episodio al que acabo de referirme sin relatar sus incidentes con detalle ha tenido el valor de agudizar nuestro ingenio y nuestras herramientas. Por desgracia, empero, los representantes principales de aquellos combates, que formaron parte de los avatares de la disciplina en los años 60 a 80 del pasado siglo, estaban tan obcecados en su empeño por purgar a la sociología de sus servidumbres ideológicas, que no se percataron de que se les echaba encima un enemigo peor aún.

La amenaza que se cernía, invisible para ellos, era la del relativismo moral y cognoscitivo, que vendría envuelto en la doctrina llamada del "posmodernismo". El posmodernismo, sencillamente, negaba la importancia de lo ideológico al declarar que todas las manifestaciones de la cultura humana eran, en todo caso, ideológicas. La conflación de verdad y opinión por parte de los partidarios de esta corriente pretendía eliminar de un plumazo la valía de toda la tradición crítica y racional instaurada por Platón y heredada con tanta dignidad por la sociología del conocimiento, que se esforzaba precisamente por distinguir entre ambas.

\section{POSMODERNISMO E IDEOLOGÍA}

Cuando declaramos que ideas, creencias y valores son ideológicos asumimos que lo son frente a ciertos criterios de objetividad, certidumbre y verdad. La componente ideológica de las expresiones humanas es entendida entonces como desviación de un universo subyacente, más firme que ellas. Ideas, creencias y valores reflejan una situación que incluye intenciones privadas, posiciones de clase y percepciones de la realidad, que deben medirse y contrastarse por su distancia o desviación de lo objetivo y verdadero, en la medida en que éste es determinable (Giner, 1997). Este supuesto, que había llegado a ser el terreno compartido por la mayoría de las teorías de la ideología, fue puesto en peligro por el auge del posmodernismo a partir de de los años 70. Como doctrina nueva, o, más correcta e irónicamente, como nueva ideología, el posmodernismo se convirtió en un riesgo sustancial para la teoría clásica de la ideología. La ideología posmoderna se hizo particularmente violenta durante los años 80 y 90 . Aunque hay ya señales de que ya amaina su temporal (Baggini, 2002: 10) sería un error desdeñarlo como si hubiera sido un episodio trivial.

Ha sido un episodio, pero de cierta envergadura. En primer lugar, más que un síntoma ha sido un síndrome de nuestros días, que merece una atención muy seria que no ha lugar aquí. En segundo lugar, y eso sí concierne a mi argumentación, sus repercusiones para la crítica sociológica de la ideología y para la parte de la epistemología que corresponde a la faena de los sociólogos (para la sociología cognitiva) merecen considerarse con alguna parsimonia. 
RIS

REVISTA INTERNACIONAL DE SOCIOLOCÍA

№ 31, Enero-Abril, 2002

SALVADOR GINER DE SAN JULIÁN

Como acabo de aseverar, el ataque de los posmodernistas contra los modernos (representados en nuestro caso por el canon sociológico) representó una amenaza superior al desencadenado por los desenmascaradores y profetas de la "inminente crisis" de la sociología "burguesa", "conservadora" o "dogmática" que les precedieron. Hasta los menos sutiles de entre estos últimos (los modernos) se sintieron inspirados por su fidelidad al espíritu tradicional de la sociología y a sus raíces morales, así como por el anhelo por la independencia de sus cultivadores frente a las servidumbres de los intereses políticos, empresariales o clasistas que les acechaban. La crítica y las acusaciones contra el sesgo ideológico de la sociología la efectuaban en nombre de una ciencia social mejor e incluso, en algunos casos, con el afán de restaurar los lazos entre la sociología y la idea de la buena sociedad. (De ahí los vínculos tradicionales de la disciplina con la política social, el reformismo y demás actividades públicas de mejora). La tarea emancipatoria entrañaba autocrítica, así como la crítica de aquellas disciplinas, como la propia sociología, que tenían una función descollante que representar en ella. Quienes estaban a favor de mantener la dimensión moral de la sociología y sus ligámenes con la filosofia moral no fueron nunca sospechosos de un radicalismo irresponsable. Desde Auguste Comte hasta la Escuela de Chicago, los sociólogos habían creído que su disciplina podía contribuir de alguna manera a mejorar la calidad del mundo sin excesos de utópica irresponsabilidad. Podemos pues criticar a los críticos (aquellos cruzados contra una sociología según ellos desvirtuada por sus servidumbres mundanas) y hasta censurarles algunos de sus desafueros, pero sería impropio ignorar sus buenas intenciones. Tampoco lo sería ignorar la solidez de algunos de sus reproches contra aquellos sociólogos incapaces de obedecer las reglas de la objetividad que ellos mismos proclamaban, o que, obedeciéndolas, seleccionaron sus datos y perspectiva para ignorar facetas de la realidad que les resultaban incómodas. Nadie afirma que no haya habido sociólogos ultraconservadores ni, peor, colaboradores de indecentes regímenes políticos, si bien conviene en tal caso recordar también los muchos que, bajo Hitler o Pinochet, lo perdieron todo, incluso sus vidas, por el mero hecho de ser sociólogos además de demócratas.

No hay manera de tratar el posmodernismo con igual rasero. No es que desafie toda descripción, pero es escurridizo. Como episodio en la historia del pensamiento occidental, ha tenido repercusiones significativas en el desarrollo de la sociología en los años 80 y 90 y no se ha derrumbado aún en los iniciales del siglo XXI. Su recepción en el seno de las disciplinas dentro de las cuales nació - la crítica literaria y cultural, alguna escuela filosófica, alguna práctica estética, como la arquitectura - surgió como proceso "natural", vinculado al agotamiento de algunas certidumbres e ideologías. (Lo que periodística y cómodamente suele evocarse con la expresión de "la caída del Muro de Berlín" sirvió para dar dramatismo, en 1989, a lo que venían fraguando otros acontecimientos: así, la misma naturaleza caleidoscópica de la televisión y 
el sincretismo y relativismo impuestos por la mundialización (Santos, 2001) coadyuvaron potentemente al desarrollo de un relativismo popular que esperaba la llegada de ideólogos de intelectual pretensión que le dieran forma y estilo de superioridad académica o cultural). El resultado de la nueva corriente cultural no fue siempre banal. En arquitectura y otras expresiones artísticas, por ejemplo, ha cambiado retazos de nuestro paisaje urbano y en algunos casos poca duda cabe que ha enriquecido nuestras percepciones estéticas (Harvey, 1996). Si bien tengo para mí que la ideología posmodernista es, por lo general, perniciosa, tampoco osaría afirmar que lo es en todos los sentidos, ni que la posmodernidad misma - que es algo muy diferente- merezca ser ignorada. Es más que probable que el tiempo presente sea testimonio de su advenimiento, aunque algunos pensemos que la interpretación que de ellos ha dado la doctrina posmodernista es sumamente inadecuada. El episodio posmodernista nos ha hecho, por lo menos, un favor: presentar una visión errónea de la situación. Es tarea nuestra demostrar que así ha sido, agradeciendo el estímulo prestado, así como presentar hipótesis y juicios más plausibles sobre ella.

La popularidad alcanzada por el posmodernismo dentro de sectores notorios de la comunidad sociológica no se debió tan sólo a la amplia atención recibida entre las disciplinas culturales - la sociología siempre ha sido notablemente sensible a lo que acaece en sus terrenos limítrofes-, sino también a otras circunstancias. Así, el agotamiento del estructuralismo creó un vacío que no estaban en condiciones de colmar (por causa de sus propias dificultades) otros enfoques, como el marxista. Este último, ocupado en sobrevivir, o bien comenzó a buscar aliados por otros terrenos - surgíría así el "marxismo analítico", entre otros derivados de un desesperado aggiornamento - o bien vió cómo sus representantes se sumían en doctrinas como la del neodarwinismo (otrora execrado) y la etnometodología o (los dioses misericordiosos nos asistan) en las marismas y médanos del mismísimo posmodernismo. El declinar del interés por el análisis de clase (y el estudio del conflicto de clases) y su sustitución por toda suerte de estudios culturales, feministas, interraciales y multiculturales reforzó la naturaleza variopinta del panorama en cuyo siempre inestable marco iba a medrar la mentalidad y doctrina posmodernistas. Por si ello no bastara, el auge de una teoría de la mundialización de nuevo cuño - no me refiero, naturalmente, a la tradicional, de Spencer y Marx a Wallerstein, pasando por Webercon su énfasis sobre el declive del Estado-nación, la centralidad de una mal explicada sociedad informacional y su declaración de que la modernidad ha expirado ya, también suministró un campo fértil para la advenediza ideología posmoderna.

Resultado de todo ello fue que, a medida que ganaba terreno la posición posmodernista, lo perdían varias interpretaciones y líneas de indagación que habían logrado cierta solidez en la sociología y cuyo programa de pesquisas estaba aún por completarse. Así, por ejemplo, la concepción del mundo moderno 
RIS

REVISTA INTERNACIONAL DE SOCIOLOCIA

№ 31, Enero-Abril, 2002

SALVADOR GINER DE SAN JULLÁN

como si de una "sociedad masa" se tratara, que había alcanzado proporciones verdaderamente hegemónicas un par de decenios antes, pareció eclipsarse del todo, aunque cualquier observador se percatará que la teoría de la sociedad masa, y dentro de ella, de la cultura de masas o mediática, está repleta de munición para el posmodernismo. La más somera lectura de La deshumanización del arte o de La rebelión de las masas nos hace ver hasta qué punto es ello cierto. Además, no poca sociología clásica se presta también a reinterpretación posmodernista: es el caso de Simmel, quien, fuera de contexto, es sin duda el más agudo precursor de la ideología posmodernista. (Lástima grande para los posmodernistas entusiastas de Simmel, que tengan que acercarse al sabio sólo ignorando cosas tan fundamentales como su neokantismo). Por si cupieran dudas, recuérdese que no faltan posmodernistas que incorporan de modo explícito a sus trabajos nociones claves propias de la teoría de la sociedad masa (Giner, 1976 y Maffesoli, 1988). No hay sorpresa: la teoría de la sociedad masa y de la súpuesta masificación del mundo moderno incluía nociones relativistas y de sincretismo cultural, así como supuestos sobre la decadencia de nuestra civilización, muy premonitorios sobre lo que después afirmarían los posmodernistas. Cosas veredes: probablemente la teoría de la sociedad masa será interpretada en el futuro, a la vez, como la última teoría general sustancial de la modernidad y la primera que, simultáneamente, presentó una visión omniabarcante del mundo posmoderno in statu nascendi.

Tras abandonar cualquier pretensión de definir la naturaleza y ramificaciones del posmodernismo doctrinario, me limitaré a recordar su énfasis sobre algo llamado "desconstrucción" por parte de sus incrédulos creyentes. La desconstrucción es un sucedáneo del viejo y acreditado análisis ideológico cultivado por la más rancia, eficaz y sólida sociología, así como por la hermenéutica moderna. (Tanto el análisis de la ideología como la hermeneútica tenían más en común de lo que los debates entre ambas dejaban entrever $\left.{ }^{6}\right)$. Como mero sucedáneo de estas corrientes, el posmodernismo carece de ningún criterio objetivo o regla de juego, salvo las compartidas por los iniciados en alguna de las sectas en que irremediablemente se dividen los fieles a su arcano evangelio. (Si cabe hablar de fidelidad en el caso de quienes la niegan como virtud identificable). Es necesario preguntarse, en todo caso, cuál es la diferencia específica entre "desconstrucción" y la fase inicial del "análisis", cuya etimología no es menester recordar aquí, y cuya venerable práctica ningún racionalista en sus cabales osaría repudiar. Mientras esperamos una respuesta por parte de algún posmodernista dispuesto al diálogo (supongamos que haylos en algún lugar)

\footnotetext{
${ }^{6}$ K.O. Apel y J. Habermas (1971) recogen notables debates entre ambas posiciones, y demuestran cómo se hallaban unidas por un mismo afán de establecer lo verdadero, más allá de todo relativismo.
} 
constatemos la manifiesta hostilidad de todo buen posmodernista contra todo humanismo, así como contra la tradición racionalista occidental basada en la posibilidad de alguna forma de universalismo moral y en la creencia de que existe la verdad (y lo verdadero) por muy difícil que sea de alcanzar. ( $O$ que existe, más modestamente, algo a lo que aspiramos y que posee el estatus epistemológico de conocimiento objetivo.)

Hay pues que reconocer que las ambiciones desmitificadoras del posmodernismo no son baladíes: nada menos que desea poner en tela de juicio los supuestos sobre los que se ha ido fraguando (con harta dificultad, contra viento y marea) la cultura científica, filosófica e intelectual occidental desde su primera formulación helénica hasta la aparición de los primeros nihilistas y su eclosión final en las huestes de los últimos relativistas, en su avatar posmodernista.

Pero es aquí donde surge la trampa, la paradoja tragicómica que levanta su burlona faz. El posmodernismo se presenta a sí mismo como filosofía desmitificadora, pero, como llevo afirmando desde el primer renglón, eso es precisamente lo que la teoría social tradicional, racional y convencional ha hecho desde siempre. He ahí la tarea a la que desde que El Antiguo Régimen de Tocqueville y La ideología alemana de Marx fueron escritas, si no antes, se ha entregado, sin duda de forma bastante competente, la sociología. La faena tradicional de la teoría sociológica de la ideología, e incluso de la sociología en general, ha incluido la desmitificación en su propio programa de trabajo. Tan es así que en el proceso de desencantamiento del mundo, y como percibieron trágicamente tanto Simmel como Weber, entra la propia sociología. La ironía, y una de las causas de la conciencia desdichada de todo cultivador de la ciencia social, es que la sociología misma, a pesar de constituir una aportación vigorosa y creadora a la cultura contemporánea, ha coadyuvado también a socavar esa misma aportación. Así, por una parte, ha contribuido a través de su propia trivialización - la sociología banal - con sus informes, encuestas y recopilaciones de datos carentes de la mínima dignidad teórica, a degradar las interpretaciones seculares del mundo social contemporáneo. Y por otra, ella misma ha promovido (junto a otras corrientes contemporáneas) el relativismo estético, moral y ontológico que han fomentado el triunfo parcial de la mentalidad y doctrinas posmodernistas (Giner, 1994).

Los daños intelectuales del posmodernismo se vinculan esencialmente a su éxito en confundir el vocabulario. Y nada hay peor que la confusión de la palabra. En él, "desconstrucción" ha suplantado a "análisis", sin añadir nada significativo, puesto que todo análisis entraña desarmar o desmontar mentalmente algo para poderlo reconstruir luego según su verdadera estructura. Por su parte, "desmitificar" es algo practicado desde siempre por la sociología (aunque la relación de ésta con el mito merezca mayor comentario, cosa a la que aludiré en seguida). Además, y de modo significativo, la expresión "discurso" ha desplazado con harta frecuencia la correspondiente expresión tradicional de 
RIS

REVISTA INTERNACIONAL DE SOCIOLOGIA

№ 31, Enero-Abril, 2002

SALVADOR GINER DE SAN JULIÁN

"ideología". Así, el "análisis del discurso" ha venido a sustituir retóricamente el análisis tradicional de la ideología, sin que se nos explique exactamente qué hay de nuevo en ello. El posmodernismo se ha dejado en su ruta (sin objetivo identificable, puesto que según él todo vale, y la verdad objetiva carece de interés) las virtudes analíticas que posee la noción clásica de ideología con sus implicaciones para el estudio socioestructural de las creencias, su esfuerzo por identificar las condiciones sociales del pensamiento científico o racional, su aportación epistemológica y su contribución a la indagación de la sociogénesis ( $\mathrm{y}$ a la génesis cultural) de la certidumbre.

No afirmo con todo esto que "desconstrucción" y "discurso" sean equivalentes precisos de lo que hasta hace poco llamábamos "análisis" e "ideología". Son más bien equivalentes funcionales de ellos en el contexto posmodernista. Pero significan cosas distintas. Así, mientras que la "ideología" se refería a una estructura de la dominación, con sus correspondientes intereses, creencias y estrategias, incorporada a un determinado orden social, "discurso" se refiere a un fenómeno mucho más desuncido de la lógica situacional en la que surge la ideología y fenómenos afines, como el de la hegemonía. No es menester ser posmodernista para asumir que el mundo está lleno de "discursos", narrativas y presentaciones, como son el discurso feminista, el ecologista, el político, el filosófico, el mediático, y asi sucesivamente. En realidad, cada uno de éstos se desglosa en muchos más, según cada cual, hasta que podamos hablar del tuyo y del mío, sin que autoridad alguna decida cual es el menos falso, el más cercano a la siempre lejana, pero anhelada, verdad por parte de quienes no son posmodernistas.

Entre tanta desagregación y desdoblamiento cabe interrogarse acerca del discurso posmodernista mismo. Supongo que los entusiastas del "discurso" reconocerán que sus pronunciamientos, tan abundantes, forman también un discurso o conjunto de ellos y no merecen mayor atención que los de los demás. Con lo cual tal vez fuera bueno que se fueran con su música a otra parte, tarea loable que no emprenden. Ingenua posición la mía, que les sugiere que se atengan a unas reglas elementales, y reconozcan que no existe razón alguna por la cual haya que tomárselos más en serio que a otras posiciones. (Para ello asumo, y de ahí la ingenuidad, que (a) poseen reglas, aunque sean distintas de las de los demás mortales, y (b) que tales reglas pueden detectarse por parte de los no iniciados). En fin, según ellos, hay sólo "discursos", puesto que en el juego interminable de la desconstrucción no sabe uno exactamente cuáles son las reglas y criterios según los cuales debe juzgarse el mundo. Juzgarlo no es posmoderno, con lo cual la kantiana noción de que pensar es juzgar -Denken ist Urteilen - se va a pique. He aquí con cuanto donaire el intrépido caballero Derrida acaba con Kant sin miramientos y brevedad suma. Derrida derriba.

La cosa llega al paroxismo cuando consideramos que este otro alguacil alguacilado no nos suministra criterio alguno que nos permita vislumbrar lo 
que constituye un discurso, incluido el suyo propio. No obstante nadie, salvo los insensatos, buscaría pelea con los lingüistas cuando, con admirable rigor, definen la noción de "discurso" como cualquier tramo de lenguaje superior al de una frase o sentencia, ni tampoco con el "análisis del discurso" que practica la respetable ciencia de la lingüística y hasta una parte de la sociología. Al contrario, ese cultivo es un aliado descollante del análisis sociológico de los fenómenos ideológicos. Por ello, la noción de discurso tal y como comenzó a instaurarse en la obra de Roland Barthes o hasta en la de Michel Foucault, en su El orden de las cosas, de 1966, merecen mucha atención. Por lo pronto, nos obligaron a atenernos más a la naturaleza del texto.

Incitado por una preocupación obsesiva por la detección de una infraestructura de intereses económicos o clasistas, así como de intenciones latentes, el análisis ideológico tradicional practicado por los sociólogos llegó a adolecer de una indiferencia notable hacia el posible contenido de verdad que poseía cada ideología determinada. La sociología tradicional, con frecuencia se olvidó de ir más allá de la detección de distorsiones y sesgos, sin buscar con la necesaria diligencia el elemento de verdad que poseen muchas de las versiones del mundo imaginadas por los hombres. En esta tarea, algunos sociólogos no estuvieron a la altura de sus colegas etnólogos, antropólogos y estudiosos de las religiones. Estos últimos parten del mito como tal, para buscar en él verdades profundas y escondidas, y establecerlas según criterios convincentes para cualquier observador racional y objetivo (Eliade, 1985). He aquí dos sendas distintas, pero convergentes: la del estudioso de la ideología que desbroza el terreno para desvelar a qué intereses corresponde y ver luego si hay algo de cierto o qué es lo que hay que evitar para alcanzar certidumbre; y la del estudioso de los mitos, que asume desde el primer momento que expresan sabiduría y verdad, pero cuyas metáforas, narraciones, imágenes y símbolos piden primero una interpretación, una comprensión respetuosa. (Por eso se entiende que algún investigador, como Mircea Eliade, haya reconocido el valor de la desmitificación, aunque haya añadido en seguida que es una vía fácil, une attitude de facilité) (Ibid. pp. 155). Ambos caminos, entendidos con sus respectivas limitaciones y también con sus aspectos fructíferos, son complementarios, mútuamente enriquecedores.

La razón por la que he tildado al posmodernismo de episodio y no lo he definido como una corriente intelectual sustancial no se debe a mis sospechas de que no pasa de ser una moda potente, sino simplemente porque carece de raíces profundas en la tradición dentro de la cual opera la filosofia y la ciencia social. Los historiadores de las ideas señalarán sin duda que el posmodernismo, aparte de sus más remotas raíces, debió comenzarse a fraguar con la penetración del "giro lingüístico" en la ciencia social. Sin duda La idea de una ciencia social de Peter Winch en 1958 puede identificarse como una fuente obvia del posmodernismo doctrinario posterior, aunque no quepa asimilar a su autor a tal escuela (Winch, 1994). En cambio uno no ve que la hermeneútica tradicional 
R I S

REVISTA INTERNACIONAL DE SOCIOLOGÍA

No 31, Enero-Abril, 2002

SALVADOR GINER DE SAN JULLÁN

permita algo semejante, puesto que al fin y al cabo también aspiraba a un entendimiento objetivo del mundo. Por su parte, una interpretación kuhniana del conocimiento científico tampoco se prestaría a una posible posmodernización: el énfasis sobre las creencias compartidas por una comunidad científica dada subrayó con brillantez el flanco débil del principio popperiano de falsación, pero Kuhn mismo jamás negó la posibilidad del progreso científico, o sea, del avance hacia el descubrimiento de la verdad. No era un relativista. Ni tampoco lo fue el Wittgenstein del Tractatus. Ni siquiera lo habían sido antes Freud y la escuela psicoanalítica, puesto que usaron una perspectiva que es canónica en los anales del análisis ideológico: los humanos distorsionamos la realidad según nuestras pasiones, traumas, experiencias e intereses. Lo mismo debe decirse de Pareto y su teoría de los "residuos" y sus "derivaciones". Una cosa es que, desde siempre, sepamos que las gentes sufren ilusiones y engaños, y que en ellos buscan refugio, consuelo y explicación, o bien usan los errores, supercherías y temores infundados de los demás para su propia ventaja; y otra que, también desde siempre, haya algo llamado "realidad" - una forma de realidad más profunda que la realidad de la neurosis, el autoengaño y el embuste ideológico - que debe ser desvelado, ya por la terapia o, más generalmente, por el proceso psicoanalítico (Delanty, 1997: 35-56), y por extensión, por la tarea del sociólogo de la cultura y del conocimiento.

Todos estos componentes cruciales del pensamiento de la última centuria asumieron la posibilidad y la deseabilidad del conocimiento objetivo. Su aportación consistió, no en invalidar las enseñanzas de la llustración, sino en refinarlas, al poner de relieve que la tarea era mucho más ardua de lo que algunos habían supuesto durante un largo período, que va desde Bacon y Descartes hasta Marx y Darwin, por lo menos. Su envidiable optimismo cognoscitivo debe atemperarse a la luz de lo que hemos ido sabiendo a partir, por poner una fecha arbitraria, desde poco antes de la Gran Guerra. Los herederos (revisionistas siempre, pero no apóstatas) de los racionalistas clásicos descubrieron nuevas dificultades e inesperadas complejidades en el establecimiento de la verdad. Pero no abandonaron, desesperados. Tan sólo constataron que la senda era cada vez más pina y tortuosa de lo previsto, sobre todo de lo previsto por parte de los positivistas y por los representantes cada vez más numerosos de la ideología cientifista. (La grey de estos últimos no ha dejado de incrementarse hasta hoy mismo, sin visos de que vaya a disminuir: he aquí una tarea nueva para el análisis sociológico de la cultura, la indagación del cientifismo como ideología, como avatar en pleno siglo XXI de cierto optimismo epistemológico populista, favorable a la comunidad científica y aún más a las empresas de I+D).

La búsqueda de la verdad exigía, pues, la identificación previa de las distorsiones ideológicas y de los malentendidos socialmente construidos, para su subsiguiente superación. Era una tarea deseable y posible. Esa es la ortodoxia de la posición llamada convencional o tradicional en ciencia social, aunque no falten matizaciones dentro de ella. Cuanto puede decirse contra posiciones como 
la de Thomas Kuhn, o la de Isaiah Berlin, respecto a su tratamiento del problema de la verdad y el del conocimiento objetivo, es que la pluralidad irreductible de los ideales humanos (en el caso de Berlin) o de los paradigmas científicos explicativos (en el de Kuhn) sólo se presta a interpretaciones relativistas y posmodernistas por parte de mentes dispuestas a ello.

\section{POR UNA SOCIOLOGÍA COGNITIVA}

El episodio al que acabo de dedicar tanta atención ha tenido consecuencias significativas tanto para la sociología cognitiva (o cognoscitiva, que viene a significar lo mismo) como para el estudio de la ideología. Ha logrado, durante la época de mayor auge, desplazar a éste de algunas de sus moradas académicas e intelectuales habituales. No mucho más. Otras causas, más difusas, han coadyuvado al declinar temporal del análisis tradicional de la ideología, y a desplazarlo de su lugar central en el seno de la sociología de la cultura y del conocimiento. A guisa de ejemplo, recordemos la periodística ideología del "fin de la historia" que se puso en boga a principio de los años 90 , concepción que, seguramente sin saberlo quien la perpetrara, es incompatible con el análisis racional de lo ideológico, puesto que la ideología es connatural a la historia, como lo es la mentalidad, la mitología y demás maneras de entender el mundo por parte de los mortales. También la noción no menos trivial y periodística de un "pensamiento único" engendrado como reacción a la agresiva ideología neoliberal contribuyó a socavar el interés científico por la ideología, por lo menos para quienes no vislumbraron alternativas viables a la hegemonía del presunto pensamiento único ni a las pretensiones extraordinariamente arrogantes acerca de la verdad económica, política y cultural de los neoliberales. La creciente oposición a estas ideas por parte de una sociedad civil incipientemente mundializada, entre otras corrientes, se encargaría, a principios del siglo XXI, de demostrar la vanidad de la afirmación del final de la historia, así como la de que exista un pensamiento único. Ya antes de esa reacción cívica, se oyeron argumentos sólidos sobre la vigorosa persistencia de la vieja separación entre izquierda y derecha, y hasta la constación de la permanencia de cosas tan aniticuadas como las ideologías o, como solía decirse, las Weltanschauungen ${ }^{7}$.

La terca presencia del análisis tradicional de la ideología a pesar de todos estos escollos y vicisitudes no se debe a la inercia. En algunos casos, los escollos estimulan ese análisis. En otros, enriquecen el enfoque. Pero sobre todo lo que cuenta es que ese análisis es insustituible e inevitable, tanto en sociología de la

\footnotetext{
${ }^{7}$ Bobbio (195), esp. Cap. III, "La diade sopravive", y ponencia sobre "The Return of the Weltanschauungen?", Universidad de Nueva York, enero, 1999.
} 
cultura, como en la del conocimiento y en el estudio del poder. Más allá de sus carencias, el análisis ideológico y la teoría del saber perduran porque no se han anquilosado, porque permanecen abiertos y porque aprenden y se estimulan con nuevos acontecimientos y críticas, directas o indirectas.

Surgen modos nuevos, más satisfactorios, de entender la ideología. Así, la producción social de conocimiento, el estudio de la interfaz cognitiva que se produce entre mente y sociedad (y no sólo entre mente y objeto de conocimiento) o a través de esta última, nos enseñan que la ideología no es sólo escollo o cedazo, sino también, con frecuencia, un medio (imperfecto) de conocimiento, de modo que hay un modo ideológico de producción cognoscitiva, por sorprendente que parezca esta noción a quienes asumen que todo en la ideología es distorsión. Toda ideología contiene elementos "verdaderos", junto a los demás. Toda ideología estimula ciertos modos de conocer, al tiempo que anula o adormece otros. Nuestra tarea es identificar estas fuentes de conocimiento.

Dar cuenta cabal del componente ideológico de la cultura nos ayuda a conseguir una explicación causal del comportamiento humano. Más específicamente, es indispensable para entender la cultura contemporánea en general y la vinculada a los medios masivos de comunicación en particular. A pesar de los altibajos en el interés por la indagación de la ideología que han generado las diversas corrientes intelectuales y modas durante los últimos decenios, así como la aparición de candidatos rivales dedicados al estudio de los mismos fenómenos bajo otros nombres o criterios (como los imprecisos, pero harto populares cultural studies, o la recién considerada doctrina posmodernista), el análisis y la crítica ideológica no han quedado nunca estancados. Es precisamente ahora cuando en mejor situación se hallan, puesto que los combates de ayer - entre ideologías como la marxista y la estructuralista conservadoraya no enturbian la tarea con sus partidismos y acaloramientos. Es una tarea que se ha liberado de sus propias cadenas ideológicas, es decir, de lo que constituyera una de las mayores paradojas de la moderna sociología.

El estudio sociológico de la ideología continúa su camino sin subterfugios ${ }^{8}$. Además, se ha producido cierta ampliación en términos de vocabulario y nociones. (Sirva de ejemplo la noción de "capital simbólico" introducida por Pierre Bourdieu). Bajo ningún concepto es posible decir que la indagación

\footnotetext{
${ }^{8}$ No es éste el lugar de enumerar las pesquisas actuales en sociología de la ideología. Pero ver N. Mouzelis (1995: 90-95) respecto a la ideología en la teoría sociológica; M. Mann (1988) para su presencia en procesos de autoridad y poder (pp. 21-24, 60-63,92-96, 124, 201 sobre ideologías 'territoriales'); K. Eder (1996: 180-183 y 187-188); S. Giner y D. Tábara (1998) para la ideología del ecologismo y C. Mongardini (1997) sobre la economía como ideología. Ver T.A. Van Dijk (1998) para una síntesis general.
} 
ha flaqueado o que la imaginación teórica ha amainado por lo que respecta a la ideología. Los únicos reveses se los debemos, como recién insinuaba, al relativismo contemporáneo y a los avances de cierto nihilismo, como el que inspira al posmodernismo. Pero su agresiva presencia agudiza nuestras mentes. Así, no pocos sociólogos de la cultura se han percatado de los riesgos que entraña una hipersociologización (si se me permite tan poco elegante expresión) de todo fenómeno social habido y por haber, incluida la conciencia humana y sus diversas expresiones. (Conocíamos desde siempre los riesgos del sociologismo, para evocar la expresión usada como arma para combatir el determinismo societario durkheimiano). Sin embargo, la aparición de los posmodernistas, con su radicalismo nihilista, tras haberlo hecho los relativistas culturales, algunos armados, a lo Winch, con los argumentos de Wittgenstein, ha producido los buenos resultados que engendran posiciones que merecen ser refutadas y que, por fortuna, pueden serlo en buena lid. Cierto es que en el combate se han pasado al enemigo algunos miembros del gremio, pero el resto ha sabido reagruparse y consolidar una sociología de la cultura y de la ideología que no merecía mayores socavamientos. También es cierto que, en el fragor de esta liza, algunos han demostrado una notable y demoledora disposición a acabar con el enemigo.

Cuando en 1995 Raymond Boudon dio a la imprenta un texto nada menor, con el título pugnaz de Lo justo y lo verdadero, no se andaba con chiquitas. Por si cupieran dudas, su subtítulo rezaba Estudios sobre la objetividad de los valores $y$ del conocimiento (Boudon, 1995). (El tenor algo mordaz de este ensayo mío que ahora toca a su fin queda corto ante el de este sociólogo). Lo crucial es que la mayoría de los sociólogos dedicados a estos menesteres de análisis cultural e ideológico no se ha mostrado indiferente ante los argumentos de los neorrelativistas, dándoles respuesta uno a uno. Da la feliz casualidad de que la sociología se halla en condiciones ideales para rebatirlos y al tiempo aprender de ellos, puesto que no en vano es un arte cuyo punto de partida se encuentra en la desconfianza ante lo que las gentes proclaman como verdadero. Su incansable búsqueda, ya sea de "residuos" paretianos, condicionamientos clasistas, intereses inconfesados, doctrinas inculcadas, y tantas otras fuentes de distorsión, muestra que no tiene por qué recibir lección alguna de los relativistas. Lo que la diferencia de ellos es que además quiere conocer la verdad. A la sociología le interesan tanto las condiciones sociales de la tergiversación, como las que producen acercamientos de los seres humanos a lo verdadero, lo bello y lo justo. (Como acabo de indicar, algunas ideologías, o facetas de ellas, pueden estimular, en vez de impedir, tales acercamientos, cosa manifiesta en el campo del arte: ni el luteranismo de Bach ni la fe tridentina de Velázquez parecen haber disminuido la calidad de su logro, más bien al contrario). Una sociología de la cultura y la ciencia que posea dignidad teórica debe ser también una sociología que aspire a conocer la estructura social de lo verdadero, o por lo menos, de la sociogénesis 
R I S

REVISTA INTERNACIONAL DE SOCIOLOCÍA

№ 31, Enero-Abril, 2002

de la verdad, dentro de la cual desempeña una descollante función lo ideológico. Por eso la llamo sociología cognitiva, como hay una psicología cognitiva o una epistemología filosófica.

Los supuestos básicos de la sociología sobre el hombre y la sociedad son universalistas. Desde su instauración, la teoría social puede entenderse como proyecto que aspira al descubrimiento de lo universal en el seno de lo relativo, lo plural y lo diverso (De Finis y Scartezzini, 1996). Si Simmel continúa siendo una de las referencias teóricas clasicas es precisamente por su habilidad para cumplir tal empeño, al establecer categorías sociales (y formas) universales en un mundo de discontinuidades, rupturas y contradicciones. Su sociología relacional se halla anclada en lo propio de toda sociedad y condición humana, en aquellos procesos (diferenciación, antagonismo, subordinación, y tantos otros) que hacen de ella lo que es, al tiempo que nunca olvida lo único, lo irrepetible, lo local y lo temporal. Su relativismo indudable - que tanto ha atraído a quienes desean olvidar los anhelos generalizadores y universalistas del arte sociológicoes más bien "relacionismo", y este último jamás es entendido como incompatible con la necesidad de constatar los elementos comunes a toda condición humana ni los rasgos generalizables a cualquier sociedad. No obstante, continúa la búsqueda de resolución de los problemas que entraña indagar teniendo siempre presentes ambos flancos. Simmel no dio con la piedra filosofal; sólo expresó, tal vez más vívidamente que nadie, las ambivalencias, las múltiples vertientes y los pluralismos a que se presta la sociedad humana. Indicó cómo las variedades cuturales, estructurales y hasta vitales del mundo merecen una atención incesante, mientras no se escamoteen los elementos profundos e invariables que subyacen tras ellas.

La tarea no es fácil. Para desconsuelo nuestro sabemos a ciencia cierta que algunas de las contradicciones, no ya entre situaciones específicas, sino también entre universales mismos, no son solubles. El mundo está repleto de incompatibilidades. Nuestras mentes, además, son portadoras de valores mútuamente inconmensurables. Hace ya mucho que Tocqueville indagó la contradicción estructural esencial entre los ideales democráticos de la libertad y la igualdad. Mucho después Berlin identificó la cuestión de la inconmensurabilidad entre valores, algo de lo que Weber estaba ya trágicamente consciente. Célebre es su referencia a los demonios para expresarlo. Pero nada hay en esta impresionante tradición que invite al nihilismo. Ciertamente nada lo justificó para estos hombres, sobre cuyo esfuerzo pretendemos construir.

Si rechazamos la búsqueda de terreno firme, rechazamos la sociología. En tal caso, vale más que nos dediquemos a algo más fácil. Lo tenemos cerca. La sociología banal siempre está a mano. La sociología banal, como ejercicio, es esencialmente distinta de la que exige un rigor que incluye un diálogo permanente con la filosofia moral, por una parte, y el desarrollo constante de la ciencia y el saber, por otro. 


\section{CONCLUSIONES}

Es comprensible que no pocos sociólogos hayan alzado objeciones contra la noción de ideología. No es necesario ser un defector o un crítico de la sociología tradicional (mainstream sociology) para mostrar reservas ante esa noción. Su uso desaliñado puede conducir al reduccionismo, como suele suceder a quienes entienden todo fenómeno cultural como si fuera una expresión ideológica. Desde tal perspectiva, todo se politiza, empezando por la teoría y el análisis mismos. Con lo cual, lo supuestamente ideológico no hace sino oscurecer aquello que queríamos iluminar, tras desvelarlo. El problema que surge de estas y otras notables dificultades, empero, es establecer otra noción (o nociones) que sean más útiles y convincentes. El simple rechazo crea más dificultades que las de su uso cauteloso como herramienta cognoscitiva.

Hemos avanzado algo, sin duda, al enriquecer el concepto e introducir varias distinciones necesarias, mientras se iban desarrollando diversos campos específicos en el estudio de la ideología. También se ha incrementado nuestro conocimiento en el terreno de los fenómenos ideológicos, como son los gremiales y profesionales en el campo de la sociología cultural (Rodríguez Morató, 1996) o en terrenos como el de la bioética, el ecologismo y otras concepciones que no pueden reducirse simplemente al análisis de clase tradicional, y de cuya importancia es imposible dudar. En este sentido, la visión de la sociedad moderna como "sociedad corporativa" en la que cada profesión, asociación, gremio y comunidad ocupacional poseen su propia mentalidad, visión del mundo y subcultura, ha resultado iluminadora también (Pérez Yruela y Giner, 1988). Los esfuerzos de esta índole, vinculados a un considerable enriquecimiento de la sociología de la cultura sobre varios frentes - desde la sociología de los bienes y consumo artístico o de los intelectuales de Pierre Bourdieu a la sociología de las filosofias de Randall Collins (Bourdieu, 1997; Collins, 1998)—, atestiguan cómo la búsqueda de la certidumbre y la verdad mediante una consideración sistemática previa de las concepciones (a menudo ideológicas) que caracterizan a cada agrupación humana, goza de muy buena salud. Finalmente, las considerables aportaciones al estudio de la ideología que se revelan a través de los medios masivos de comunicación y, sobre todo, la propiamente mediática, endémica por así decirlo a los medios, han reforzado la indagación sobre la producción social de las interpretaciones y los valores. En ningùn caso han socavado el legado heredado. Sólo cabe reconocer la vastedad del campo, así como el peligro de fragmentación de nuestros estudios.

Una vez más, estos desvelos contemporáneos tienen un pasado reciente importante. Desde que Mannheim iniciara la distinción entre la ideología propiamente dicha y la utopía, y Gramsci propusiera el análisis de la dominación en términos de hegemonía esencialmente cultural, el acervo de 
RIS

REVISTA INTERNACIONAL DE SOCIOLOGÍA

№ 31, Enero-Abril, 2002

SALVADOR GINER DE SAN JULIÁN

nuestros conocimientos no ha hecho sino acrecentarse, como las aportaciones que acabo de mencionar demuestran plenamente. Tanto es así que parece como si ya fuera llegando la hora adecuada, el kairós por así decirlo, de incorporar la sociología cognitiva, la de la ideología y la de la cultura en un conjunto complejo. Trátase de una tarea tan ardua como prometedora. Sólo lograremos realizarla con un mínimo de dignidad si sabemos respetar el legado de nuestros mayores, si asumimos sin titubeos que hay conocimiento objetivo y que existe una verdad que mora en algún lugar ignoto. La empresa para los de nuestro oficio consiste en ir en pos de ella con las herramientas, imaginación y enseñanzas que la sociología nos suministra. Si desacreditamos la senda hacia la certidumbre y ponemos la siempre distante verdad en tela de juicio, desacreditaremos también la sociología y banalizaremos nuestra búsqueda hasta hacerla superflua.

\section{REFERENCIAS BIBLIOGRÁFICAS}

ABERCROMBIE, N. et al., (comps.) (1990), Dominant Ideologies, Londres, Unwin Hyman.

APEL, K.O., J. HABERMAS, et al., (1971), Hermeneutik und Ideologiekritik Francfurt, Suhrkamp (ed. de 1977).

ARON, R. (1955), L'opium des intellectuels, París, Calmann-Lévy.

BELL, D. (1960), The End of Ideology, Glencoe, Free Press.

(1976), The Cultural Contradictions of Capitalism, Londres, Heinemann.

BAGGINI, J. (2002), "Death of an Idea”, Prospect, $\mathrm{n}^{\circ} 78$, Septiembre, pp. 10.

BIRNBAUM, N. (1971), Toward a Critical Sociology, Nueva York, Oxford University Press. Traducción castellana: Hacia una sociología crítica, Barcelona, Península.

BOBBIO, N. (1994), Destra e sinistra, Roma, Donzelli.

BOUDON, R. (1986), L'Idéologie, ou l'origine des idées reçues, París, Fayard.

(1990), L'art de se persuader, París, Fayard.

(1995), Le juste et le vrai: études sur l'objectivité de la connaissance, París, Fayard.

BOURDIEU (1997), Méditations pascaliennes, París, Seuil.

COLFAX, J.D. y J.L. ROACH (comps.) (1971), Radical Sociology, Nueva York, Basic Books.

COLLINS, R. (1998), The Sociology of Philosophies: A Global Theory of Intellectual Change, Harvard University Press (Belknap). 
DE FINIS, G. y R. SCARTEZZINI (comps.) (1996), Universalità e Differenza, Milán, Franco Angeli. Edición española a cargo de S. Giner y R. Scartezzini (1996): Universalidad y diferencia, Madrid, Alianza.

DELANTY, G. (1997), Social Science: Beyond Constructivism and Realism, Buckingham, Open University Press.

EDER, K. (1996), The Social Construction of Nature, Londres, Sage.

ELIADE, M. (1985), L'épreuve du labyrinthe, París, Pierre Belfond.

FERRAROTTI, F. (1972), Una sociologia alternativa, Bari, De Donato Editore.

GINER, S. (1965), "Sociología dirigida", Promos, n 33, enero, pp. 18-20.

(1974), Mass Society, Londres, Martin Robertson, y Nueva York, Academic Press.

(1987), "Sociology and Moral Philosophy", Revue Internationale de Sociologie, $\mathrm{n}^{\circ} 3, \mathrm{pp}$ 47-96. Versión castellana "Sociología y filosofia moral", en V. Camps (comp.), Historia de la ética, Barcelona, Crítica, Vol. III, 2000.

(1994), "An Uncertain Victory: The Sociological Intelligence", Annals of the International Institute of Sociolgy, Vol. IV, pp. 145-162, Versión castellana revisada "Una incierta victoria: la inteligencia sociológica”, en C. Nieto (comp.), Saber, sentir, pensar, pp. 275-310, Madrid, Debate, 1997.

(1997), "Intenciones humanas, estructuras sociales: para una lógica situacional", M. Cruz, (comp.), Acción humana, pp. 21-126, Barcelona, Ariel.

GINER, S. y J.D. TÁBARA (1998), "Piedad cósmica y racionalidad ecológica", Revista Internacional de Sociología, $\mathrm{n}^{\circ}$ 19-20, pp. 41-67.

GOULDNER, A. (1970), The Coming Crisis of Western Sociology, Londres, Heinemann.

GURVITCH, G. (1966), Les cadres sociaux de la connaissance, París, Presses Universitaires de France.

HARVEY, D. (1996), Justice, Nature and the Geography of Difference, Oxford, Blackwell.

McLENNAN, G. (2000), "Sociology's Eurocentrism and the 'Rise of the West' Revisited", European Journal of Social Theory, Vol.3, $\mathrm{n}^{\circ} 3$, pp. 275-292.

MILLS, C.W. (1959), The Sociological Imagination, Nueva York, Oxford University Press.

MONGARDINI, C. (1997), Economia come ideologia, Milán, Franco Angeli.

MOUZELIS, N. (1995), Sociological Theory: What Went Wrong? Diagnoses and Remedies, Londres, Routledge. 
R I S

REVISTA INTERNACIONAL DE SOCIOLOGía

№ 31, Enero-Abril, 2002

MOSCOVICI, S. (1988), La machine à faire des dieux, Paris, Fayard.

MURPHY, J.W. (1988), "Making Sense of Post-Modern Sociology”, British Journal of Sociology, Vol. XXXIX, nº 4, pp. 600-614.

PELLICANI, L. (1995), La società dei giusti, Milán, Etaslibri.

PÉREZ YRUELA, M. y S. GINER (comps.) (1988), El corporatismo en España, Barcelona, Ariel.

RODRÍGUEZ MORATÓ, A. (1996), Los compositores españoles. Un análisis sociológico, Madrid, CIS y SGAE.

SANTOS, B. DE SOUSA (comp.) (2001), Globaliçaça, fatalidade ou utopia?, Oporto, Ediçoes Afrontamento.

SEBRELI, J.J. (1992), El asedio a la modernidad: critica del relativismo cultural, Barcelona, Ariel.

SOROKIN, P. (1956), Fads and Foibles in Modern Sociology and Related Sciences, Chicago, Henry Regnery Company.

VAN DIJK, T.A. (1998), Ideology, a Multidiciplinary Approach, Londres, SAGE.

WINCH, P. (1994), Comprender una sociedad primitiva, Barcelona, Paidós.

WIEVIORKA, M. (1988), Societés et terrorisme, París, Fayard. 